\title{
Lack of accumulation of paralytic shellfish poisoning (PSP) toxins in the tintinnid ciliate Favella taraikaensis feeding on the toxic dinoflagellate Alexandrium tamarense
}

\author{
T. Kamiyama*, T. Suzuki \\ Tohoku National Fisheries Research Institute, Fisheries Research Agency, 3-27-5, Shinhama, Shiogama, \\ Miyagi 985-0001, Japan
}

\begin{abstract}
To clarify the fate of paralytic shellfish poisoning (PSP) toxins in planktonic food webs, toxin contents of the planktonic ciliate Favella taraikaensis feeding on Alexandrium tamarense and of the surrounding seawater were examined in laboratory experiments using high-performance liquid chromatography fluorometric detection. During 5 or $6 \mathrm{~d}$ incubation periods in 3 replicate experiments, F. taraikaensis actively ingested $A$. tamarense and reached 8 to 17 -fold initial density values. At the end of the incubation, the toxin concentration of the suspension consisting mostly of $F$. taraikaensis, which had increased by feeding on $A$. tamarense, was much lower than that of $A$. tamarense cells. The toxin content of pure F. taraikaensis, which was analyzed based on 165 to 200 individuals of $F$. taraikaensis directly taken from the suspension, was also lower than the cellular toxicity of $A$. tamarense. Toxin concentration in filtrates of the $F$. taraikaensis suspension was significantly higher than that in filtrates of the suspension containing only A. tamarense. Furthermore, the total toxin concentration in the F. taraikaensis suspension (particulates plus the filtrate) was almost equivalent to that in the $A$. tamarense suspension in each trial. We conclude that the PSP toxins of $A$. tamarense are not accumulated in F. taraikaensis over $24 \mathrm{~h}$ in the course of predator-prey interactions, and the toxins are rapidly excreted from the cell body of the ciliate.
\end{abstract}

KEY WORDS: Ciliate $\cdot$ Grazing $\cdot$ Alexandrium tamarense $\cdot$ PSP $\cdot$ Accumulation

\section{INTRODUCTION}

The toxic dinoflagellate Alexandrium tamarense (Lebour) Balech is an important causative species of paralytic shellfish poisoning (PSP) throughout the world (Hallegraeff 1993). Outbreaks of PSP due to A. tamarense cause serious economic losses for shellfish culture industries. Understanding the mechanism of occurrence of A. tamarense blooms is of importance in predicting and ultimately preventing PSP outbreaks. So far, physiological and ecological information on $A$. tamarense has been accumulated in laboratory experiments and field research (e.g. Anderson 1996, Yamamoto \& Tarutani 1999, Hamasaki et al. 2001).
The role of zooplankton feeding is potentially a critical factor in regulating harmful algal blooms. Information on feeding responses of zooplankton on toxic phytoplankton including Alexandrium spp. has been summarized in Turner et al. (1998). Several studies have reported that some copepods ingest Alexandrium tamarense with no apparent damage (White 1981, Turner \& Anderson 1983, Teegarden \& Cembella 1996), whereas others are adversely affected (Ives 1985, 1987, Turriff et al. 1995). Colin \& Dam (2003) revealed that feeding rates of copepods previously exposed to Alexandrium fundyense were not affected by this toxin-containing alga, while ingestion rates of the same copepod species without such exposure were 
reduced. Active feeding of zooplankton implies the possibility of transfer of PSP toxins to higher trophic levels (Turner \& Tester 1997). In some species of copepods, PSP toxins of Alexandrium spp. were accumulated in the body (Turriff et al. 1995, Teegarden \& Cembella 1996, Turner et al. 2000). The accumulated toxins possibly cause mortality of planktivorous fish (White 1980, 1981), and toxins in fecal pellets produced by copepods feeding on $A$. tamarense may also influence benthic food webs (Hamasaki et al. 2003). However, Teegarden et al. (2003) reported that some copepod species in the Gulf of Maine, USA, retain in their body a very small fraction of PSP toxins ingested by feeding on Alexandrium spp. and effectively disperse the remainder into the surrounding environment.

Protozoan grazers (ciliates and heterotrophic dinoflagellates) ingest PSP-producing dinoflagellates (like Alexandrium spp.), and in the majority of cases the protozoan grazers can grow very well on a mono-diet of these algae at low prey densities, irrespective of their cellular PSP content (Hansen 1989, Hansen et al. 1992, Kamiyama et al. 2005). At high cell densities of Alexandrium spp., the predators are killed by toxic exudates released into the medium by the algae (Hansen 1989, Hansen et al. 1992). These exudates were originally believed to be PSP toxins based on indirect evidence. However, recent research suggests that the toxic effect of the exudates is most likely due to some currently unknown toxins (Tillmann \& John 2002).

In spite of the negative effects of Alexandrium spp. on protozoan grazers, field studies suggest that grazing by planktonic ciliates can greatly influence the dynamics of Alexandrium tamarense blooms (Watras et al. 1985, Sorokin et al. 1996). In western Japan, blooms of $A$. tamarense occur in spring (Itakura et al. 2002). This season partly overlaps with the occurrence of the tintinnid ciliate Favella taraikaensis (Kamiyama \& Tsujino 1996). If protozoan plankton can actively feed on A. tamarense, then their role as a vector must be considered in the transfer mechanisms of PSP toxins to higher trophic level organisms through the marine food chain, because protozoan plankton are important prey for mesozooplankton (Pierce \& Turner 1992). So far, little information on the fate of PSP toxins has been reported for protozoa feeding on toxic dinoflagellates, although Jeong et al. (2003) reported that the heterotrophic dinoflagellate Polykrikos kofoidii retained PSP toxins by feeding on the toxic dinoflagellate Gymnodinium catenatum. The present study was conducted to elucidate the fate of the PSP toxins of A. tamarense when F. taraikaensis actively fed on this alga in laboratory experiments.

\section{MATERIALS AND METHODS}

Cultures of Alexandrium tamarense and Favella taraikaensis. Strains of A. tamarense (Alk985) and F. taraikaensis were isolated from the seawater of Hiroshima Bay, Japan, in May 1998 and April 2004, respectively. The strain of $A$. tamarense was maintained in modified SWM3 medium (Itoh \& Imai 1987) with soil extracts. Stock cultures of $F$. taraikaensis in autoclaved, filtered seawater enriched with EDTA and trace-metal solution (a ciliate culture medium) (Stoecker et al. 1988) were maintained by supplying the non-toxic dinoflagellate Heterocapsa triquetra at an order of magnitude of $10^{4}$ cells ml ${ }^{-1}$ as a food source.

Growth and ingestion rates of Favella taraikaensis. The following 3 replicate experiments (Expts A to C) were carried out: 3 to $7 \mathrm{~d}$ before the experiments, a part of the Alexandrium tamarense culture in the early stationary growth phase was supplied to the stock culture of $F$. taraikaensis to acclimate the ciliate to $A$. tamarense. For each experiment, four $250 \mathrm{ml}$ polycarbonate flasks containing $152 \mathrm{ml}$ of $A$. tamarense suspension were prepared by the addition of A. tamarense culture to the ciliate culture medium to give an initial concentration of 540 to 752 cells ml ${ }^{-1}$. Then, $F$. taraikaensis was added at an initial density of $0.7 \mathrm{ind}$. $\mathrm{ml}^{-1}$ to 3 of the 4 flasks as experimental treatments by collecting - using a micropipette and a stereomicroscope with a dark-field illumination attachment-each individual from the stock culture. The other flask (A. tamarense only suspension) was used as a control treatment. During each experiment, the flasks were incubated on a rotator $(1 \mathrm{rpm})$ at $15^{\circ} \mathrm{C}$ and under light conditions of $15 \mu \mathrm{mol}$ photons $\mathrm{m}^{-2} \mathrm{~s}^{-1}$ and a $12 \mathrm{~h}$ light: $12 \mathrm{~h}$ dark cycle. Every 1 or $2 \mathrm{~d}$ from 1 to $4 \mathrm{~d}$ after the initiation of the incubation, the suspension in each flask was well mixed, taking care not to damage the ciliates; subsequently, $5 \mathrm{ml}$ of suspension was collected, and living F. taraikaensis ciliates were counted using a stereographic microscope. Also, 0.2 to $2 \mathrm{ml}$ of the suspension was fixed with buffered formalin (final concentration 2 to $4 \%$ ), and A. tamarense cells were counted using an inverted microscope.

Growth and ingestion rates of Favella taraikaensis were estimated from the increase in F. taraikaensis and the decrease in the Alexandrium tamarense concentration between 2 sampling days. The daily specific growth rate $\left(\mu, \mathrm{d}^{-1}\right)$ of $F$. taraikaensis was calculated as:

$$
\mu=\left[\ln \left(F_{n+t}\right)-\ln \left(F_{n}\right)\right] \times t^{-1}
$$

where $F_{n}$ and $F_{n+t}$ are densities (ind. $\mathrm{ml}^{-1}$ ) of $F$. taraikaensis on the first day and $t \mathrm{~d}$ after, respectively. The geometric mean concentration of $A$. tamarense and the geometric mean density of $F$. taraikaensis were calculated in experimental treatments during $t \mathrm{~d}$ based 
on equations given in Heinbokel (1978). According to the methods detailed in Frost (1972) and Heinbokel (1978), the ingestion rates of $F$. taraikaensis were calculated from the decrease in the A. tamarense concentration in the experimental treatment, which was corrected for the change in the $A$. tamarense concentration in the control treatment during the $t \mathrm{~d}$. The period between the start and the first sampling day was regarded as the acclimation time, and the growth and ingestion rates during this period were not calculated.

Treatment of plankton samples for PSP toxin analysis. Before the start of Expts A and B, $10 \mathrm{ml}$ of each stock culture of Alexandrium tamarense (concentration 1.48 to $2.7 \times 10^{4}$ cells $\mathrm{ml}^{-1}$ ) was sampled to clarify the characteristics of the algal toxin composition. Then, at the start of the incubation in all experiments, 40 to $50 \mathrm{ml}$ of the suspension in the control treatment was sampled to measure the initial PSP toxin contents of $A$. tamarense. At the end of the incubation (Day 5 or 6), when the $A$. tamarense concentration decreased to 30 cells ml $\mathrm{m}^{-1}$ or less in the experimental treatments, 40 to $80 \mathrm{ml}$ of the suspensions was collected from each flask for both treatments. A particulate sample was concentrated on a Nucleopore polycarbonate filter (pore size $10 \mu \mathrm{m}, 25 \mathrm{~mm}$ diameter) under gravity pressure, and then the sample with the filter was transferred to $0.5 \mathrm{ml}$ of $0.5 \mathrm{~N}$ acetic acid solution and stored (ca. $-25^{\circ} \mathrm{C}$ ) until analysis. Then, each seawater sample that passed through the Nucleopore filter was again filtered with a Millex filter unit $(0.45 \mu \mathrm{m}$ pore size, $25 \mathrm{~mm}$ diameter), and the final filtrate was stored at ca. $-25^{\circ} \mathrm{C}$ until analysis.

Treatment of filtrate samples for PSP toxin analysis. For analysis of the filtrate samples, we modified the method by using solid phase extraction (SPE) on a charcoal column, as described by Suzuki et al. (2003). Briefly, $25 \mathrm{ml}$ of filtrate was adjusted to $\mathrm{pH} 5.0$ with $0.1 \mathrm{~N}$ acetic acid and loaded into a disposable Pasteur pipette (Fisher Scientific, upper inside diameter, $6.5 \mathrm{~mm}$ ) packed with $1.6 \mathrm{ml}$ of activated charcoal (Wako); it was then washed with $2 \mathrm{ml}$ of distilled water. Toxins were eluted with $2 \mathrm{ml}$ of $50 \%$ ethanol containing $4 \%$ acetic acid, and the toxins were dissolved in $500 \mu \mathrm{l}$ of $0.5 \mathrm{~N}$ acetic acid after evaporating the solvent by flowing $\mathrm{N}_{2}$ gas at $35^{\circ} \mathrm{C}$. The dissolved PSP toxins were analyzed as described below.

Treatment of Favella taraikaensis collected directly for PSP toxin analysis. At the end of incubation in each experiment, 165 to 200 individuals of F. taraikaensis washed with the culture medium were collected using a micropipette and put into a $1.5 \mathrm{ml}$ microcentrifuge tube with a small amount of medium (0.24 to $0.93 \mathrm{ml}$ ). Then, $0.5 \mathrm{ml}$ of $0.5 \mathrm{~N}$ acetic acid was poured into the tube, and the tube was stored in a freezer (ca. $-25^{\circ} \mathrm{C}$ ).
PSP toxin analysis. For analysis of PSP toxins we used the high-pressure liquid chromatography fluorometric detection (HPLC-FD) system developed by Oshima (1995). The plankton samples were thawed and then sonicated. Then, all samples were filtered with an ultra-filtration kit (Ultra-free MC, Millipore). A 10 or $20 \mu \mathrm{l}$ aliquot of the ultra-filtrated sample was injected into the HPLC-FD system. The PSP toxin content of the sample was determined by comparing the peak areas of each toxin with those of the standard. Gonyautoxins-1,4 (GTX1,4), GTX2,3, N-sulfocarbamoyl-11-hydrosulfate toxins $(\mathrm{C} 1,2)$ and neosaxitoxin (neoSTX) were provided by Japan Food Research Laboratories (Tokyo, Japan). Particulate and dissolved toxin values were expressed as pmol ml-1.

From original information on the HPLC-FD method (Oshima 1995), the toxin detection limits in the present study are considered to be 0.01 and $0.02 \mathrm{pmol} \mathrm{ml}^{-1}$ for particulate and dissolved fractions, respectively, and 7 to $9 \mathrm{fmol}$ ind..$^{-1}$ for $F$. taraikaensis collected directly.

Volume-specific PSP toxin and its retention. Volume-specific PSP toxin contents (fmol $\mu^{-3}$ ) were estimated from the toxin content of each organism in the present study and from the cell/individual volumes of Alexandrium tamarense and Favella taraikaensis, which are assumed to be $3.26 \times 10^{3}$ and $1.27 \times 10^{4} \mathrm{\mu m}^{3}$ (Kamiyama et al. 2005), respectively.

PSP toxin retention of Favella taraikaensis $(R, \%)$ was calculated from the following equation based on the data at the end of the experiment for each trial:

$$
R=\frac{T S-(E A \times T A)}{(C A-E A) \times T A} \times 100
$$

where TS $\left(\mathrm{fmol} \mathrm{ml} \mathrm{m}^{-1}\right.$ ) is the toxin concentration of particulates in the experimental treatment, TA (fmol cell ${ }^{-1}$ ) is the toxin contents of Alexandrium tamarense in the control treatment and $C A$ (cells $\mathrm{ml}^{-1}$ ) and $E A$ (cells $\mathrm{ml}^{-1}$ ) are the concentrations of $A$. tamarense in the control and experimental treatments, respectively.

Recovery of PSP toxins for the filtrate samples. By the procedure described above for the filtrate samples, the dissolved PSP toxins were simultaneously concentrated. The recoveries of total toxin (GTX1 to $4+\mathrm{C} 1,2$ ) contents (fmol) by the SPE on the charcoal column in the present study were $76.0 \pm 7.2 \%(n=3)$. Hence, the toxin contents in the filtrate samples were corrected by applying a factor of 1.3. Because GTX1, 4 were reductively converted to GTX2,3 in the present SPE procedure, the apparent recoveries of GTX1, 4 and GTX2,3 were $29.0 \pm 4.6$ and $286 \pm 45 \%$, respectively $(n=3)$. Hence, we do not discuss the toxin compositions of the filtrate samples in the present study.

It is likely that the recovery of neoSTX by the charcoal column (ca. $53.5 \%$, T. Suzuki et al. unpubl. data) is lower than that of the other toxins (Suzuki et al. 2003), 
although the recovery was not examined in this study. In the present study, the contents of neoSTX in the stock culture of Alexandrium tamarense were very low, and the toxin was not detected in either the plankton or the filtrate sample of any treatment, due to the relatively low sensitivity of neoSTX in the present HPLCFD. Hence, the toxin content of neoSTX was not considered for analysis of toxicity data in any treatment.

\section{RESULTS}

\section{Growth and ingestion of Favella taraikaensis on a diet of Alexandrium tamarense}

In the 3 replicate experiments, the concentration of A. tamarense in the control treatment fluctuated within $\pm 20 \%$ of the initial values during the 5 to $6 \mathrm{~d}$ period, while the mean concentration in each experimental treatment decreased to $<4 \%$ of the initial values (Fig. 1), except for 1 treatment in Expt B in which $F$. taraikaensis did not grow. This exception was probably due to artificial stress in the ciliates caused by experimental procedures; the data from this treatment were, thus, excluded from the following results. While the concentration of $A$. tamarense rapidly decreased, the mean density of $F$. taraikaensis in each experiment rapidly increased and reached 8- to 17 -fold initial density values, again with the exception of 1 treatment in Expt B.

Generally, high growth rates were recorded when the ingestion rates were high, except for Days 2 and 3 in Expt B (Fig. 2). The maximum growth rates and ingestion rates of Alexandrium tamarense recorded in

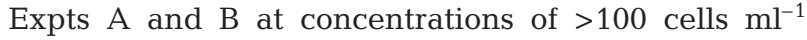
ranged from 0.9 to $1.5 \mathrm{~d}^{-1}$ and from 3.1 to 5.2 cells ind. ${ }^{-1} \mathrm{~h}^{-1}$, respectively. The relatively low growth and ingestion rates in the Day 4 to 5 and Day 5 to 6 periods were due to lower concentrations of $A$. tamarense.

\section{PSP toxin of particulate and dissolved fractions}

The toxin composition data of Alexandrium tamarense cells in the stock culture in Expts A and B indicated that the components of PSP toxin (average \pm range) consisted of $\mathrm{C} 1,2$ toxin (40.1 \pm 0.8 molar \%), GTX1, 4 (58.1 \pm 0.4 molar \%), GTX2, 3 (0.8 0.2 molar $\%)$ and neo-STX $(1.0 \pm 0.2$ molar \%). In all experiments, the cellular toxin content of $A$. tamarense in the control treatment at the start of incubation was 21.4 to $34.9 \mathrm{fmol} \mathrm{cell}^{-1}$. Among the toxins, neo-STX could not be detected in any of the particulate and filtrate samples in any experiment, due to relatively low sensitivity of neo-STX compared to the other toxins. The dis- solved toxin concentration in experimental treatments was measurable in all cases, and particulate toxins were detected from some samples in the experimental treatments; typical HPLC-FD chromatograms of dissolved and particulate toxins in the experimental treatments are depicted in Fig. 3 together with those of the standard toxins.

In Expts $\mathrm{A}$ to $\mathrm{C}$, the particulate toxin contents in the control treatment (Alexandrium tamarense suspen-

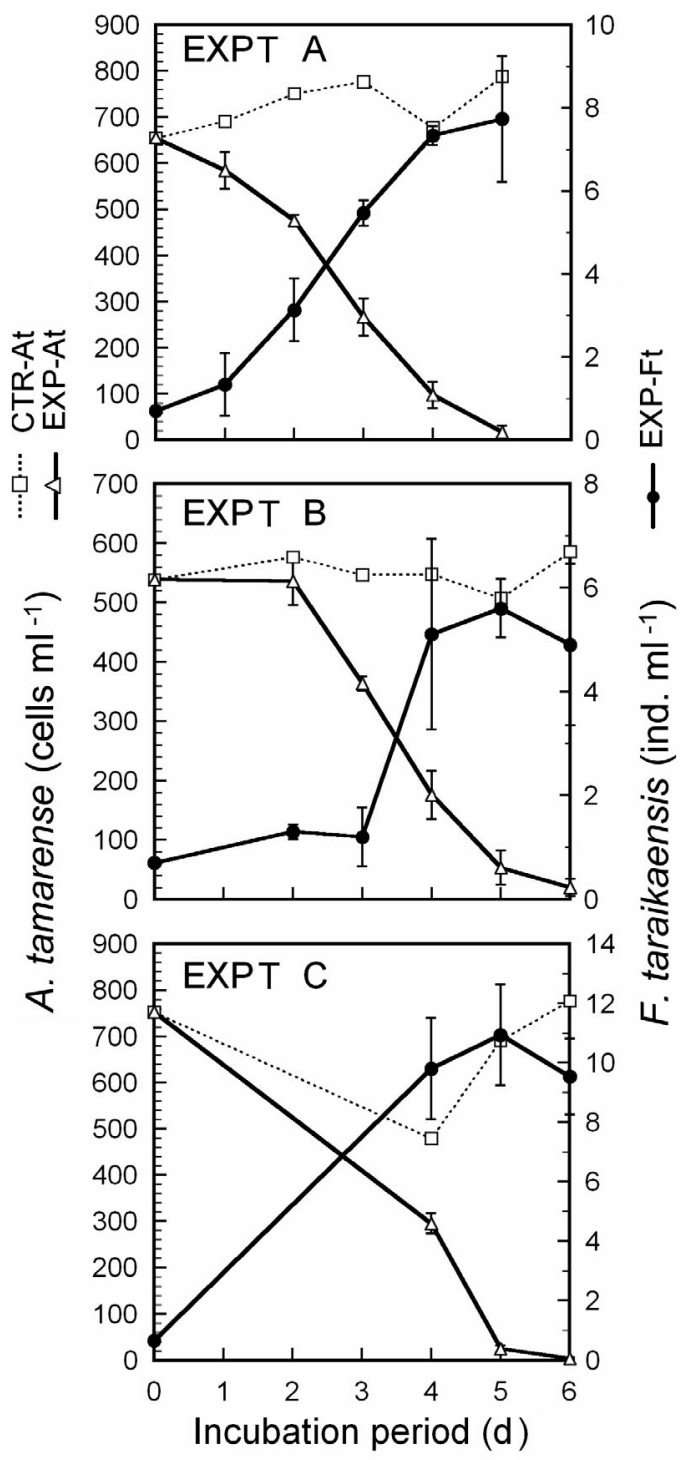

Fig. 1. Favella taraikaensis feeding on Alexandrium tamarense. Changes in the concentration of $A$. tamarense for control treatments (CTR-At) and experimental treatments (EXPAt) and in the density of $F$. taraikaensis for experimental treatments (EXP-Ft). Three replicate experiments were carried out (Expt A to Expt $\mathrm{C}$ ). Error bars denote the standard error of the mean $(n=3)$, and the range of the mean $(n=2)$ in Expt B. One treatment in Expt B in which F. taraikaensis did not grow was excluded from the data 


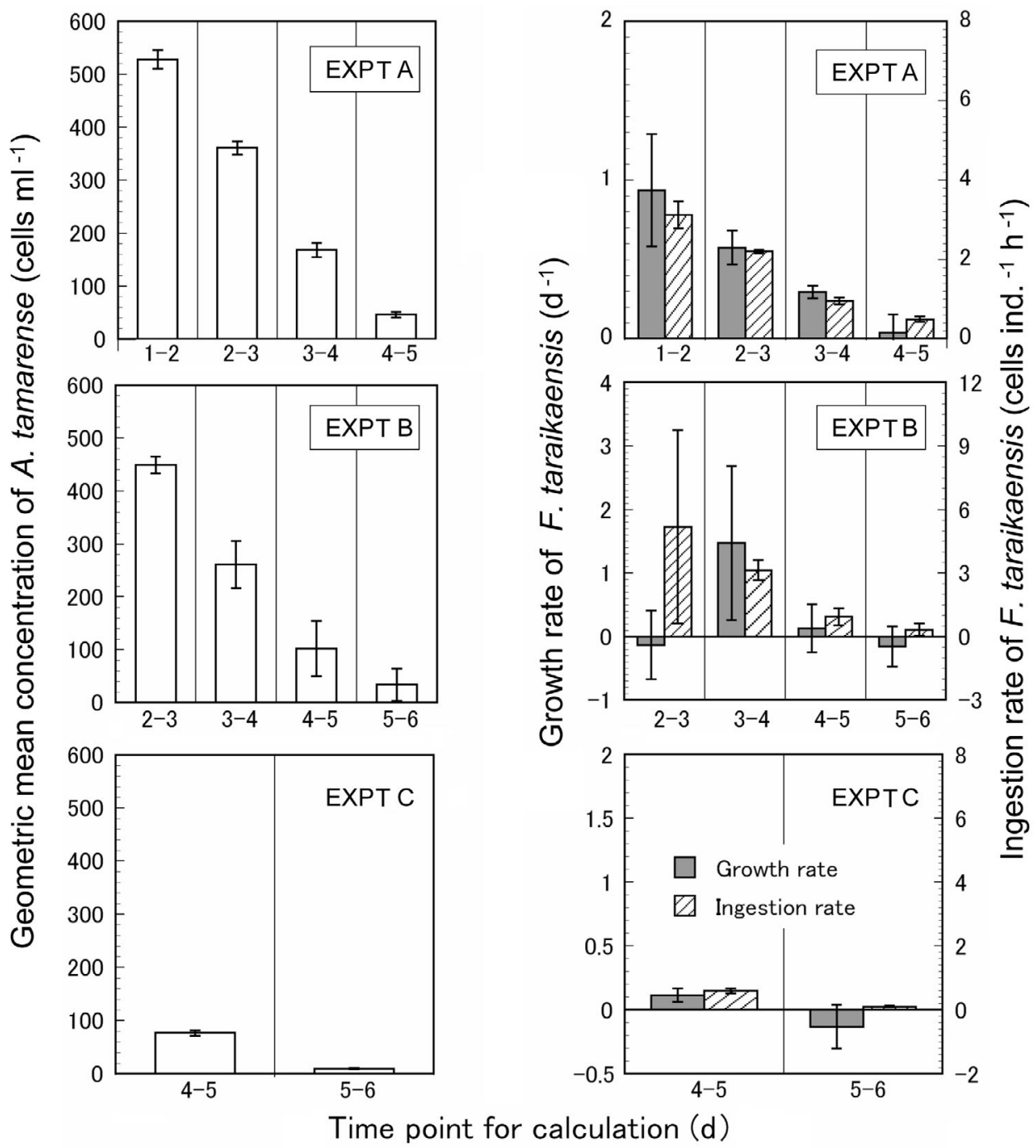

Fig. 2. Favella taraikaensis feeding on Alexandrium tamarense. (left) Geometric mean concentration of A. tamarense and (right) growth and ingestion rates of $F$. taraikaensis on a diet of $A$. tamarense for each incubation day in 3 replicate experiments (Expt A to Expt C). Error bars denote the standard error of the mean $(n=3)$, and the range of the mean $(n=2)$ in Expt B. One treatment in Expt B in which F. taraikaensis did not grow was excluded from the data

sion) at the start of incubation and at the end of incubation ranged from 16.1 to 21.3 and from 10.0 to $20.9 \mathrm{pmol} \mathrm{ml}^{-1}$, respectively (Fig. 4). The mean cellular toxins in 3 trials were not significantly different between the start and end of the incubation (paired Student's $t$-test, $\mathrm{df}=2, \mathrm{p}=0.254$ ). Particulate PSP toxin contents in the experimental treatment in which the suspension mostly consisted of Favella taraikaensis, ranged from 0 to $0.7 \mathrm{pmol} \mathrm{ml}^{-1}$. The mean toxin content in 3 trials was significantly lower than the value in the control treatments (Student's $t$-test with Welch's correction for comparison of treatments, $\mathrm{df}=2, \mathrm{p}<0.05$ ). Cellular toxin contents of $F$. taraikaensis collected by sampling individuals ranged from 0 to $22 \mathrm{fmol}$ cell $^{-1}$ at the end of incubation. The volume-specific toxin contents were equivalent to a range of 0 to $1.77 \times$
$10^{-3} \mathrm{fmol} \mathrm{m}^{-3}$, which is lower than the values for $A$. tamarense in all cases (Fig. 5). The PSP toxin retention in $F$. taraikaensis at the end of incubation was $<2 \%$ in all trials.

PSP toxin concentrations of the dissolved fraction in control treatments ranged from 1.3 to $2.4 \mathrm{pmol} \mathrm{ml}^{-1}$ at the start and from 6.0 to $11.8 \mathrm{pmol} \mathrm{ml}^{-1}$ at the end of the experiments, respectively (Fig. 4). Although the differences of the dissolved toxin contents in the control treatment between the start and end of the incubation were not significant (paired Student's $t$-test, $\mathrm{df}=2$, $p=0.065$ ), the dissolved toxin concentrations increased after the incubation on all occasions. At the end of the experiment in each trial, toxin concentration in the experimental treatment was significantly higher than that in the control treatment (Student's $t$-test for com- 


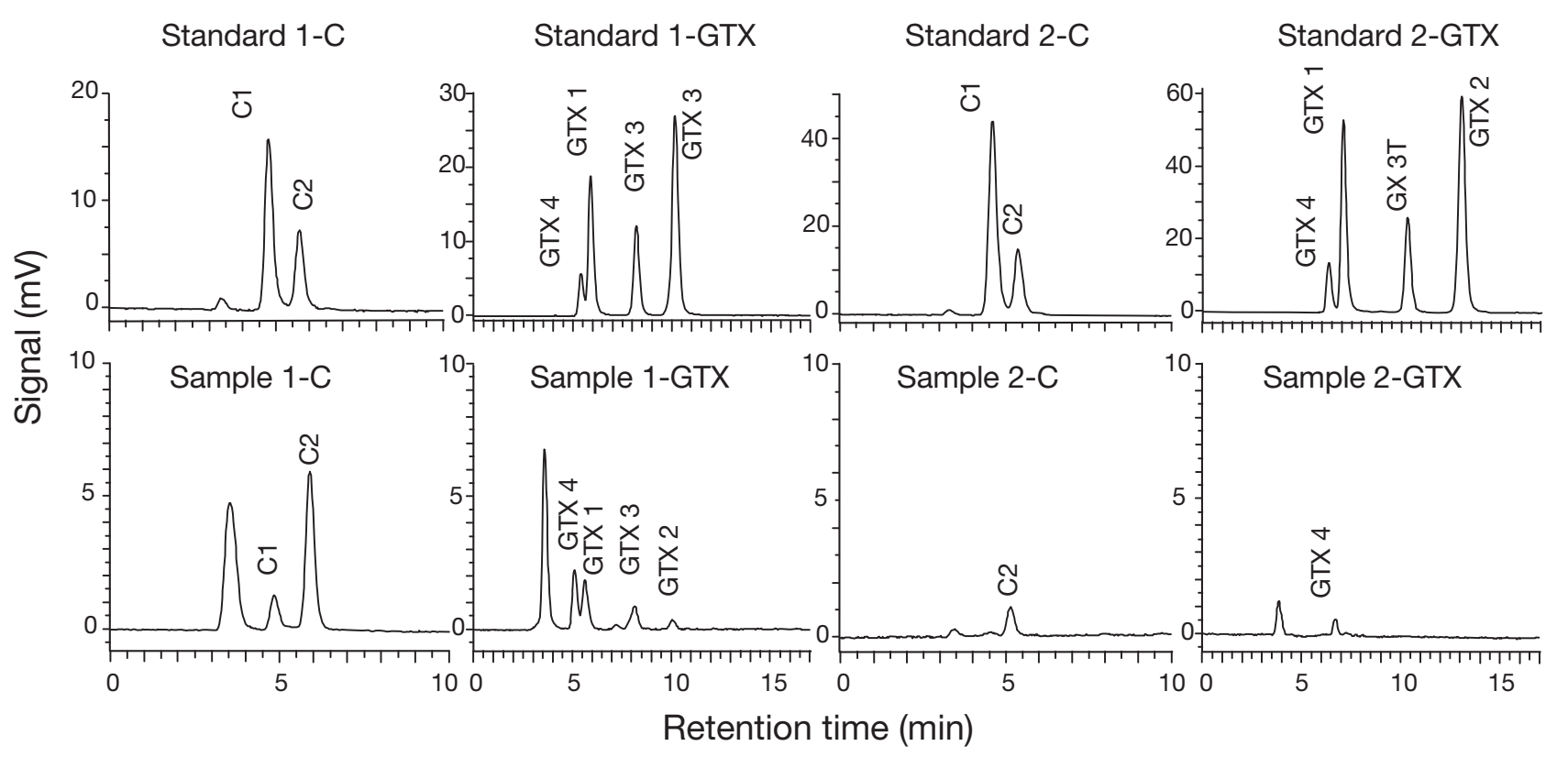

Fig. 3. Sample and standard chromatogram from HPLC-FD analysis of paralytic shellfish poisoning (PSP) toxins in the dissolved fraction (Sample 1-C or 1-GTX and Standard 1-C or 1-GTX, respectively) and in the particulate fraction (Sample 2-C or 2-GTX and Standard 2-C or 2-GTX, respectively). C1 and C2: N-sulfocarbamoyl C-toxins 1 and 2; GTX1 to 4: Gonyautoxins 1, 2, 3 and 4

parison of the treatments, $\mathrm{df}=4, \mathrm{p}<0.05)$. As for the total toxin contents in the particulate and filtrate fractions, the value in the control treatment was usually equivalent to that in the experimental treatment in all trials (Student's $t$-test for comparison of the treatments, $\mathrm{df}=4, \mathrm{p}=0.95$ ) (Fig. 4).

\section{DISCUSSION}

\section{Growth and ingestion response of Favella taraikaensis on a diet of Alexandrium tamarense}

The maximum growth rate (0.9 to $\left.1.5 \mathrm{~d}^{-1}\right)$ and the carbon-specific maximum ingestion rate (5.3 to $8.8 \mathrm{ng}$ $\mathrm{C}$ ind..$^{-1} \mathrm{~h}^{-1}$ ), which was calculated assuming that the cell carbon content of $A$. tamarense is $1.7 \mathrm{ng} \mathrm{C}$ cell $^{-1}$ (Kamiyama et al. 2005) in the present study, were both comparable to data in previous studies of Favella spp. feeding on dinoflagellates (0.4 to $1.2 \mathrm{~d}^{-1}$ and 0.9 to 17.6 ng C ind.$^{-1} \mathrm{~h}^{-1}$, respectively) (Table 3 in Kamiyama et al. 2005). These results suggested that the toxins of $A$. tamarense did not cause adverse effects on feeding and growth responses of F. taraikaensis. Also, Kamiyama et al. (2005) reported active feeding and growth of F. taraikaensis feeding on A.tamarense, and that the grazing impact of this ciliate possibly influences the dynamics of $A$. tamarense blooms.

The toxin contents of Alexandrium tamarense (21.4 to $34.9 \mathrm{fmol} \mathrm{cell}^{-1}$ ) used in the present study were rela- tively low for the general range of toxic contents for this species (24.6 to $280 \mathrm{fmol} \mathrm{cell}^{-1}$ ) in coastal waters (Oshima et al. 1990, Sakamoto \& Kotani 1998). Previous laboratory experiments have revealed that the PSP toxin contents in A. tamarense (120 to $14100 \mathrm{fmol}$ cell ${ }^{-1}$ ) influenced the growth of Favella ehrenbergii (Hansen 1989). Higher toxic levels probably cause different growth and feeding responses in F. taraikaensis, while it is also possible that Alexandrium spp. carry toxins other than those involved in PSP, causing the mortality of microzooplankton (Tillmann \& John 2002).

\section{PSP toxin in the plankton and filtrates}

At the end of the incubation in the present study, the suspension mainly consisting of Favella taraikaensis in the experimental treatment retained very low contents of PSP toxins. The toxicity of F. taraikaensis collected directly from the suspension was also very low, even though F. taraikaensis had actively fed on Alexandrium tamarense cells during the incubation. Faint toxicity of $F$. taraikaensis was probably due to ingested $A$. tamarense cells that had not been digested in the food vacuoles. These results indicate that even though $F$. taraikaensis feeds on A. tamarense, the PSP toxins are hardly accumulated in the population of the ciliate, although there is a possibility that higher toxin concentrations from $A$. tamarense are retained in individuals of F. taraikaensis for a short period ( $<24 \mathrm{~h}$ ) at the high- 
est concentration of $A$. tamarense. On the contrary, the toxin content in the filtrate of the $F$. taraikaensis suspension was significantly higher than that in the $A$. tamarense suspension, indicating that $F$. taraikaensis rapidly excretes the toxins into the surrounding seawater.

In the control treatment, the toxin concentrations in the dissolved fraction increased at the end of the experiments compared to those at the start in all trials. The cause of the increase is unknown, but changes in environmental conditions such as nutrient concentrations and growth phases of Alexandrium tamarense

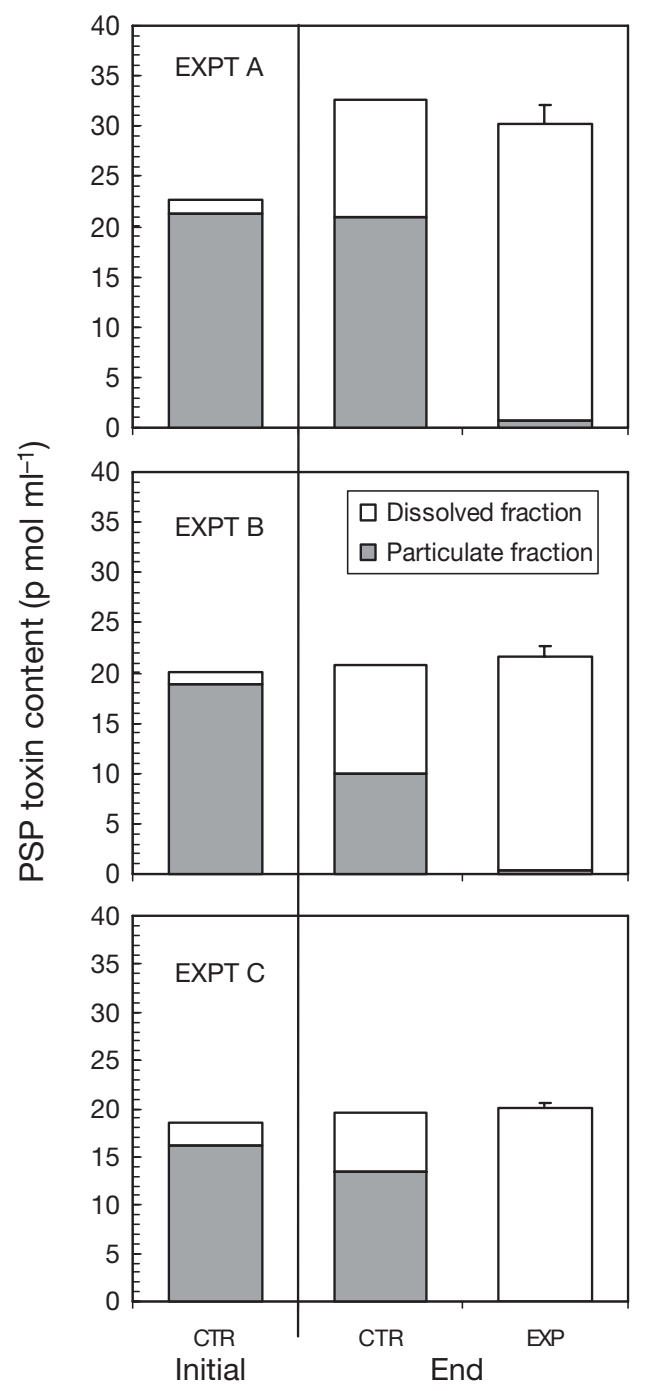

Fig. 4. Favella taraikaensis feeding on Alexandrium tamarense. PSP toxin concentration of the plankton and filtrates at the start and end of incubation. Plankton in the control treatment (CTR) consisted of A. tamarense only and plankton of the experimental treatment (EXP) at the end of incubation consisted mostly of $F$. taraikaensis (A. tamarense concentration remained at $\leq 30$ cells $\mathrm{ml}^{-1}$ ). Other details as in Fig. 1 during incubation may have stimulated the release of cellular toxins from $A$. tamarense into the surrounding seawater. Although we cannot assume that all of the dissolved PSP toxins in the experimental treatments at the end of the incubation were caused by the feeding of Favella taraikaensis, the very low contents in particulate fractions in the experimental treatment suggest that feeding by F. taraikaensis strongly promoted the release of toxins into the surrounding seawater.

As for heterotrophic dinoflagellates feeding on toxic dinoflagellates, Jeong et al. (2003) reported that the PSP toxin retention of Polykrikos kofoidii feeding on

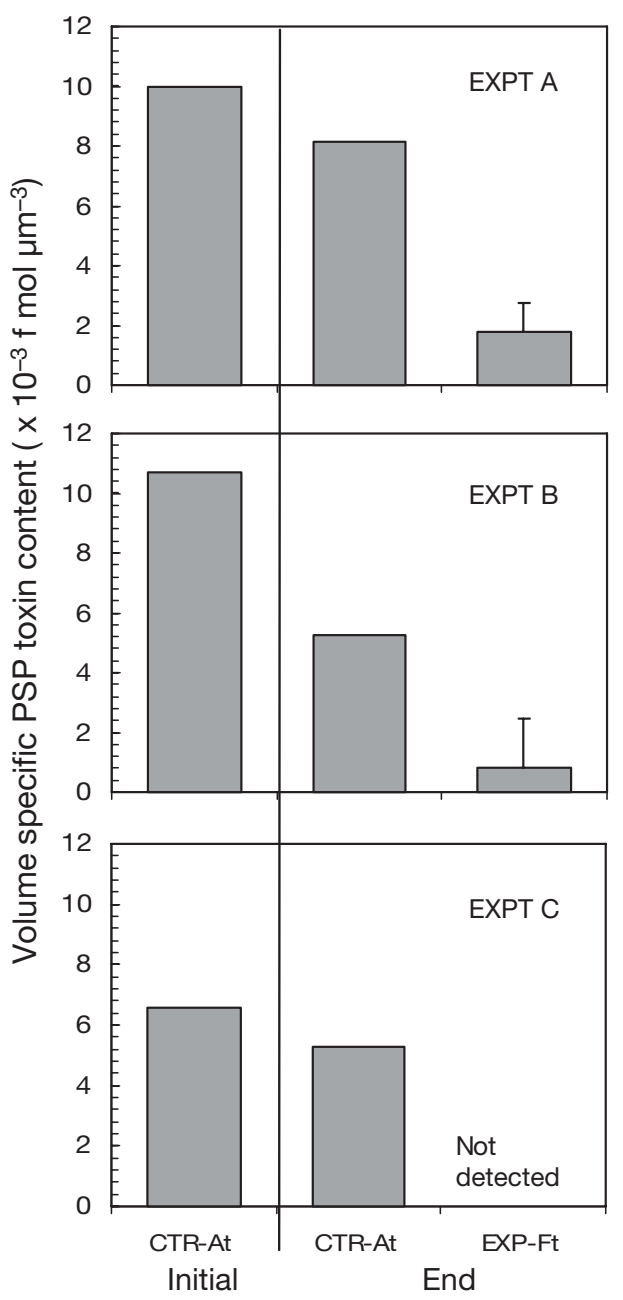

Fig. 5. Favella taraikaensis feeding on Alexandrium tamarense. Volume-specific PSP toxin contents of $A$. tamarense (CTR-At) at the start and end of incubation and $F$. taraikaensis (EXP-Ft) at the end of incubation. The values were calculated from the toxin contents and cell volume of individual organisms; the former was analyzed based on a sample consisting of 165 to 200 individuals of $F$. taraikaensis collected directly from the suspension at the end of the incubation; the latter was assumed to be $3.26 \times$ $10^{3} \mu^{3}$ for $A$. tamarense and $1.27 \times 10^{4} \mu^{3}$ for F. taraikaensis (Kamiyama et al. 2005). Other details as in Fig. 1 
the toxic dinoflagellate Gymnodinium catenatum was estimated to be ca. $66 \%$, and the toxicity of $P$. kofoidii rapidly decreased after starvation and reached an undetectable level after $96 \mathrm{~h}$ of starvation. In the present study, the retention $(<2 \%)$ of toxins by Favella taraikaensis at the end of the incubation was considerably lower than that of $P$. kofoidii. Because $F$. taraikaensis fed on Alexandrium tamarense just before the end of the incubation ( 2 to 12 cells ind.$^{-1}$ during the last $24 \mathrm{~h}$ of incubation), it is likely that excretion of toxins rapidly occurs after feeding. Although the functional toxicity of PSP to F. taraikaensis is unknown, the rapid excretion of toxins probably allows active feeding and growth responses of $F$. taraikaensis to $A$. tamarense without the ciliate being adversely influenced.

Interestingly, at the end of the incubation, the total toxin contents in the suspension (plankton plus the filtrate) in the experimental treatments were almost equal to those in the control treatments (Fig. 4). This result implies that Favella taraikaensis cannot decompose PSP toxins in the digestive process of Alexandrium tamarense, and we conclude that the toxins are simply released into the surrounding seawater. It was difficult to evaluate the change in toxin composition in the excretion process from $A$. tamarense to the surrounding seawater, because the chemical transformation of GTX1, 4 to GTX2, 3 in filtrate samples occurred in the concentration process for PSP analysis. The dynamics of PSP toxins during the feeding process in zooplankton feeding on $A$. tamarense remain to be clarified in the future.

\section{Ecological implications}

Active excretion of PSP toxins from Favella taraikaensis into the surrounding seawater is an important finding when considering the dynamics of PSP toxins in pelagic food chains. Although there is no other information on the transfer of PSP toxins between microzooplankton and Alexandrium tamarense, if the grazing of microzooplankton such as $F$. taraikaensis is not influenced by the toxic effects of $A$. tamarense and if microzooplankton assemblages do not accumulate the toxins, this grazing process probably plays a significant role as a sink in the dynamics of PSP toxins in pelagic food chains. This is a favorable scenario for fisheries industries in coastal waters. However, unless the toxins that are excreted into the seawater are rapidly decomposed, the dissolved toxins may be concentrated in the seawater and may cause physiological problems in various organisms.

This is the first report dealing with the budget of PSP toxins among Alexandrium tamarense, ciliates and the surrounding seawater. To clarify the dynamics of PSP toxins in pelagic food chains, further studies on the feeding response of various microzooplankton to toxic algae in general and elucidation of the fate of toxins are needed.

Acknowledgements. We thank Dr. Y. Matsuyama, National Research Institute of Fisheries and Environment of Inland Sea, for providing the seawater sample containing Favella taraikaensis from Hiroshima Bay. This work was partly funded by a grant from the Fisheries Research Agency of Japan. This paper was isssued as FRA-TNFRI-B80.

\section{LITERATURE CITED}

Anderson DM (1996) Physiology and bloom dynamics of toxic Alexandrium species, with emphasis on life cycle transitions. In: Anderson DM, Cembella AD, Hallegraeff GM (eds) Physiological ecology of harmful algal blooms. NATO Adv Sci Inst G 41:29-48

Colin S, Dam H (2003) Effects of the toxic dinoflagellate Alexandrium fundyense on the copepod Acartia hudsonica: tests of mechanisms that reduce ingestion rate. Mar Ecol Prog Ser 248:55-65

Frost BW (1972) Effects of size and concentration of food particles on the feeding behavior of the marine planktonic copepod Calanus pacificus. Limnol Oceanogr 17:805-815

Hallegraeff GM (1993) A review of harmful algal blooms and their apparent global increase. Phycologia 32:79-99

Hamasaki K, Horie M, Tokimitsu S, Toda T, Taguchi S (2001) Variability in toxicity of the dinoflagellate Alexandrium tamarense isolated from Hiroshima Bay, western Japan, as a reflection of changing environmental conditions. J Plankton Res 23:271-278

Hamasaki K, Takahashi T, Uye S (2003) Accumulation of paralytic shellfish poisoning toxins in planktonic copepods during a bloom of the toxic dinoflagellate Alexandrium tamarense in Hiroshima Bay, western Japan. Mar Biol 143: 981-988

Hansen PJ (1989) The red tide dinoflagellate Alexandrium tamarense: effects on behaviour and growth of a tintinnid ciliate. Mar Ecol Prog Ser 53:105-116

Hansen PJ, Cembella AD, Moestrup Ø (1992) The marine dinoflagellate Alexandrium ostenfeldii: paralytic shellfish toxin concentration, composition, and toxicity to a tintinnid ciliate. J Phycol 28:597-603

Heinbokel JF (1978) Studies on the functional role of tintinnids in the southern California Bight. I. Grazing and growth rates in laboratory cultures. Mar Biol 47:177-189

Itakura S, Yamaguchi M, Yoshida M, Fukuyo Y (2002) The seasonal occurrence of Alexandrium tamarense (Dinophyceae) vegetative cells in Hiroshima Bay, Japan. Fish Sci 68:77-86

Itoh K, Imai I (1987) Rafido so (Raphidophyceae). In: Japan fisheries resource conservation association (ed) A guide for studies of red tide organisms. Shuwa, Tokyo, p 122-130 (in Japanese)

Ives JD (1985) The relationship between Gonyaulax tamarensis cell toxin levels and copepod ingestion rates. In: Anderson DM, White AW, Baden DG (eds) Toxic dinoflagellates. Elsevier, Amsterdam, p 413-418

Ives JD (1987) Possible mechanisms underlying copepod grazing responses to levels of toxicity in red tide dinoflagellates. J Exp Mar Biol Ecol 112:131-145 
Jeong HJ, Park KH, Kim JS, Kang H and 5 others (2003) Reduction in the toxicity of the dinoflagellate Gymnodinium catenatum when fed on by the heterotrophic dinoflagellate Polykrikos kofoidii. Aquat Microb Ecol 31: 307-312

Kamiyama T, Tsujino M (1996) Seasonal variation in the species composition of tintinnid ciliates in Hiroshima Bay, the Seto Inland Sea of Japan. J Plankton Res 18:2313-2327

Kamiyama T, Tsujino M, Matsuyama Y, Uchida T (2005) Growth and grazing rates of the tintinnid ciliate Favella taraikaensis on the toxic dinoflagellate Alexandrium tamarense. Mar Biol 147:989-997

Oshima Y (1995) Postcolumn derivatization liquid chromatographic method for paralytic shellfish toxins. AOAC Int J 78:528-532

Oshima Y, Sugino K, Itakura H, Hirota M, Yasumoto T (1990) Comparative studies on paralytic shellfish toxin profile of dinoflagellates and bivalves. In: Granéli E, Sundström B, Edler L, Anderson DM (eds) Toxic marine phytoplankton. Elsevier, New York, p 391-396

Pierce RW, Turner JT (1992) Ecology of planktonic ciliates in marine food webs. Rev Aquat Sci 6:139-181

Sakamoto S, Kotani Y (1998) Variation of paralytic shellfish toxin contents and composition in Alexandrium tamarense collected at Kure Bay, Hiroshima Prefecture. Bull Nansei Natl Fish Res Inst 31:45-52 (in Japanese with English abstract)

Sorokin YI, Sorokin PY, Ravagnan G (1996) On an extremely dense bloom of the dinoflagellate Alexandrium tamarense in lagoons of the Po River delta: impact on the environment. J Sea Res 35:251-255

Stoecker DK, Silver MW, Michaels AE, Davis LH (1988) Obligate mixotrophy in Laboea strobila, a ciliate which retains chloroplasts. Mar Biol 99:415-423

Suzuki T, Ichimi K, Oshima Y, Kamiyama T (2003) Paralytic shellfish poisoning (PSP) toxin profiles and short-term detoxification kinetics in mussels Mytilus galloprovincialis fed with the toxic dinoflagellate Alexandrium tamarense. Harmful Algae 2:201-206

Teegarden GJ, Cembella AD (1996) Grazing of toxic dinoflagellate, Alexandrium spp., by adult copepods of coastal Maine: implications for the fate of paralytic shellfish toxins in marine food webs. J Exp Mar Biol Ecol 196:145-176

Editorial responsibility: Otto Kinne (Editor-in-Chief), Oldendorf/Luhe, Germany
Teegarden GJ, Cembella AD, Capuano CL, Barron SH, Durbin EG (2003) Phycotoxin accumulation in zooplankton feeding on Alexandrium fundyense-vector or sink? J Plankton Res 25:429-443

Tillmann U, John U (2002) Toxic effects of Alexandrium spp. on heterotrophic dinoflagellates: an allelochemical defense mechanism independent of PSP-toxin content. Mar Ecol Prog Ser 230:47-58

Turner JT, Anderson DM (1983) Zooplankton grazing during dinoflagellate blooms in a Cape Cod embayment, with observations of predation upon tintinnids by copepods. PSZN I Mar Ecol 4:359-374

Turner JT, Tester PA (1997) Toxic marine phytoplankton, zooplankton grazers, and pelagic food webs. Limnol Oceanogr 42:1203-1214

Turner JT, Tester PA, Hansen PJ (1998) Interactions between toxic marine phytoplankton and metazoan and protistan grazers. In: Anderson DM, Cembella AD, Hallegraeff GM (eds) Physiological ecology of harmful algal blooms. NATO Adv Sci Inst G 41:453-474

Turner JT, Doucette GJ, Powell CL, Kulis DM, Keafer BA, Anderson DM (2000) Accumulation of red tide toxins in larger size fractions of zooplankton assemblages from Massachusetts Bay, USA. Mar Ecol Prog Ser 203:95-107

Turriff N, Runge JA, Cembella AD (1995) Toxin accumulation and feeding-behavior of the planktonic copepod Calanus finmarchicus exposed to the red-tide dinoflagellate Alexandrium excavatum. Mar Biol 123:55-64

Watras CJ, Garcon VC, Olson RJ, Chisholm SW, Anderson DM (1985) The effect of zooplankton grazing on estuarine blooms of the toxic dinoflagellate Gonyaulax tamarensis. J Plankton Res 7:891-908

White AW (1980) Recurrence of kills of Atlantic herring (Clupea harengus harengus) caused by dinoflagellate toxins transported through herbivorous zooplankton. Can J Fish Aquat Sci 37:2262-2265

White AW (1981) Marine zooplankton can accumulate and retain dinoflagellate toxins and cause fish kills. Limnol Oceanogr 26:103-109

Yamamoto T, Tarutani K (1999) Growth and phosphate uptake kinetics of the toxic dinoflagellate Alexandrium tamarense from Hiroshima Bay in the Seto Inland Sea, Japan. Phycol Res 47:27-32

Submitted: June 21, 2005; Accepted: December 8, 2005 Proofs received from author(s): June 27, 2006 